\title{
Variability and Heritability Studies in the Recombinant Inbred Lines (F8) of Langulmota/Sambamahsuri Derivatives of Rice (Oryza sativa L.)
}

\author{
Rashad Khan*, B.K. Senapati, P.L. Sangeeta and Shaik Shamim Ahmed \\ ${ }^{1}$ Department of Genetics and Plant Breeding, Bidhan Chandra KrishiViswavidyalaya, \\ Mohanpur-741252, Nadia, West Bengal, India \\ *Corresponding author
}

\begin{tabular}{l} 
Ke y w o r d s \\
Recombinant inbred \\
lines, Variability, \\
Heritability, \\
Genetic advance \\
\hline Article Info \\
\hline $\begin{array}{l}\text { Accepted: } \\
\text { 07 March } 2019 \\
\text { Available Online: } \\
\text { 10 April } 2019\end{array}$ \\
\hline
\end{tabular}

A B S T R A C T
Thirty Recombinant Inbred Lines (RILs) of F 8 generation derived from Langulmota/Sambamahsuri were tested for variability of yield and yield attributing characters along with parents and three check varieties during kharif-2016, at the Instructional farm, Bidhan Chandra Krishi Viswa Vidyalya, Jaguli, Nadia, West Bengal. The lines S2, S28, S10, S24, S17 shown yield advantage of 4.78\%, 4.58\%, 4.1\%, 3.48\%, and $2.7 \%$ respectively as compared to both parents and checks. Lines S2, S10, S17, S5 and S3 shown yield advantage of $35.83 \%, 34.94 \%, 33.12 \%, 32.94 \%$ and $32.59 \%$ respectively as compared to best check variety only. Characters like number of florets per panicle, followed by number of grains per panicle, plant height at maturity, floret fertility (\%) recorded high phenotypic and genotypic variance. High estimates of PCV and GCV was obtained for number of florets per panicle, number of grains per panicle, panicles per plant, panicle weight, 1000 grain weight and number of secondary branches per panicle. High heritability estimate was observed for all the characters except grain L/B ratio. High estimates of heritability coupled with high genetic advance were obtained for number of florets per panicle and number of grains per panicle and plant height. Thus, it may be suggested that these characters are predominantly controlled by additive genes.

\section{Introduction}

Rice (Oryza sativa $\mathrm{L}$.) is the most important food crop in the world, directly feeding more than $60 \%$ population especially in Asia. It belongs to the family Graminae and subfamily Oryzoidae. It is associated with wet, humid climate, though it is not a tropical plant. It is also the staple food across Asia and is becoming increasingly important in Africa and Latin America. Rice accounts for 35\%-
$60 \%$ of the caloric intake of the three billion Asians (Guyer et al., 1998). It is primarily a high energy or high caloric food containing around $78.2 \%$ carbohydrates, $6.8 \%$ protein. Research efforts focused on development of high-yielding varieties and adoption of modern production technologies resulted in enhanced production leading to selfsufficiency in the country. Along with yield, grain and nutritional quality has also become a primary consideration in rice breeding 
programs not only in India but also in various rice growing countries across the world. The strategy in the present agriculture is to produce adequate quantity of food from the available acreage to meet the requirement of ever expanding world population. Population of Recombinant Inbred Lines (RILs) can serve as a powerful tool to cover the complexity of yield related traits. They are the recombinant output from which superior stabilized segregants can be directly used as breeding lines. The present study is therefore an attempt to characterize RIL population and find out superior genotypes of rice suitable for the Gangetic plains of West Bengal by assessing the RILs of Langulmota/ Sambamahsuri derivatives understand the differences among the rice varieties with respect to yield and its attributing characters.

\section{Materials and Methods}

The experimental materials consisted of $30 \mathrm{~F}_{8}$ progenies developed from Langulmota/ Sambamahsuri derivatives at Regional Research Station, new alluvial zone, sub center- Chakdah, Nadia. Along with two parents and three check varieties viz., Dhanrasi, SwarnaSub-1, Sabita.The experiment was conducted during Aman(Kharif) season of year 2015-16 at Instructional farm, Bidhan Chandra Krishi Viswavidyalya, Jaguli, Nadia, West Bengal. The experimental field is situated at latitude$23^{\circ} 5^{\prime} \mathrm{N}$, longitude $88^{\circ} 59^{\prime} \mathrm{E}$ and altitude of $9.75 \mathrm{~m}$ ( above mean sea level) in New Alluvial Zone of West Bengal, India.The experiment was conducted in Randomized Block Design with two replications. The seedlings were transplanted at a spacing of $20 \mathrm{~cm}$ from row to row and $15 \mathrm{~cm}$ from plant to plant and recommended agronomic package of practices were followed during the crop growth period. The observations were recorded from five randomly selected plants from each replication for each genotype for the 19 characters namely Days to $50 \%$ flowering, Days to maturity, Plant height (cm), Number of panicles per plant, Panicle weight $(\mathrm{g})$, Panicle length $(\mathrm{cm})$, Number of primary branch per panicle, Number of secondary branch per panicle, Number of florets per panicle, Number of grains per panicle, Florets fertility (\%),1000 grain weight (g), Grain length (mm), Grain breadth (mm), Grain L/B ratio, Kernel length $(\mathrm{mm})$, Kernel breadth (mm), kernel L/B ratio, Grain yield per plant. The genetic parameters were estimated based on the method suggested by Al Jibouri et al., (1958) and Johnson et al., (1955). The statistical analysis was done using the software OPSTAT.

\section{Results and Discussion}

Analysis of variance (ANOVA) revealed significance differences among all the rice genotypes against all of the characters studied (Table 1). Thus, there is a potential for improving these traits through precise selection.

Mean performance of 19 quantitative traits in 30 RILs of Langulmota/Sambamahsuri derivatives along with parents and check varieties i.e. Sabita, Dhanrasi and Swarna Sub-1 respectively are presented in table 2.1 and 2.2. Wide ranges of variability were found for days to $50 \%$ flowering among the genotypes. It varied from 99.00 to 121.00 days i.e., days after sowing (DAS). The earliest days to $50 \%$ flowering observed in $\mathrm{S}_{22}$ (99.0 DAS).Days to maturity varied from 130.5 to 151.0 days. Earliest maturity was recorded for $\mathrm{S}_{22}$ (130.5 DAS), followed by $\mathrm{S}_{30}$ (134.5 DAS), $\mathrm{S}_{17}$ (134.5 DAS). The Plant height among the genotypes varied widely. It ranged from 69.0 to $163.5 \mathrm{~cm}$. The number of panicle per plant ranged from 5.0 to 13.0. The maximum number of panicles per plant was observed in $\mathrm{S}_{28}$ (13) followed by $\mathrm{S}_{24}$ (11.5), Swarna Sub-1(11.5), $S_{18}(11.5)$, and the 
panicle weight ranged from 1.31 to $4.74 \mathrm{~g}$. Highest panicle weight was recorded in Langulmota $(5.11 \mathrm{~g})$ followed by $\mathrm{S}_{13}(4.74 \mathrm{~g})$, $\mathrm{S}_{10}(4.74 \mathrm{~g}), \mathrm{S}_{21}(3.43 \mathrm{~g})$.

$\mathrm{S}_{21}$ recorded maximum (14.56) number of primary branches per panicle followed by $S_{10}$ (13.16) and $S_{20}$ (12.58). Number of florets per panicle ranged from (96.30 to 420.29). The highest number was recorded against $S_{13}$ (420.29) and followed by $S_{10}$ (358.12).Maximum number of grains per panicle was recorded against the genotype $S_{13}$ (236.30) followed by $S_{10}$ (220.37) and $S_{11}$ (186.5). $\mathrm{S}_{7}$ was found to have the maximum florets fertility $(86.43 \%)$ followed by $S_{22}$ $(85.72 \%)$ and $\mathrm{S}_{28}(84.34 \%)$. Highest test weight was recorded for Langulmota $(30.76 \mathrm{~g})$ followed by $\mathrm{S}_{6}(29.03 \mathrm{~g})$ and Sabita $(25.38 \mathrm{~g})$. The range for grain length varied from $(6.08$ to $9.87 \mathrm{~mm}$ ). Maximum length was observed in the genotype $S_{25}$ followed by Sabita( 9.76 $\mathrm{mm})$ and $\mathrm{S}_{30}(9.25 \mathrm{~mm})$. The grain breadth was found to be maximum in $\mathrm{S}_{6}$, and Langulmota $(3.09 \mathrm{~mm})$ followed by $\mathrm{S}_{27}(3.00$ $\mathrm{mm})$, and Sabita $(2.90 \mathrm{~mm})$. Highest grain L/B ratio was recorded against $\mathrm{S}_{8}(4.41)$ followed by $S_{30}$ (4.32) and $S_{22}$ (3.93). Maximum kernel length was found in $S_{30}$ $(7.78 \mathrm{~mm})$ followed by $\mathrm{S}_{8}(6.84 \mathrm{~mm})$, Sabita $(6.81 \mathrm{~mm})$ and $S_{18}(6.57 \mathrm{~mm})$, while Dhanrasi showed highest kernel breadth followed by $\mathrm{S}_{21}$ and $\mathrm{S}_{26}(2.92 \mathrm{~mm}, 2.73 \mathrm{~mm}$ and $2.66 \mathrm{~mm})$ respectively. Highest kernel $\mathrm{L} / \mathrm{B}$ ratio was recorded by $S_{8}$ (3.58) followed by Sabita (3.51), $S_{30}(3.23)$ and $S_{25}(3.14)$.

A considerable degree of variation (13.34 to $30.63 \mathrm{~g}$ ) was observed for grain yield per plant with a mean of $24.85 \mathrm{~g} . \mathrm{S}_{2}(30.63 \mathrm{~g})$ recorded highest yield per plant followed by, $\mathrm{S}_{28}$ $(30.57 \mathrm{~g}), \mathrm{S}_{10}(30.43 \mathrm{~g}), \mathrm{S}_{24}(30.25)$ and $\mathrm{S}_{17}$ $(30.02 \mathrm{~g})$, with Yield advantage of $4.78 \%$, $4.58 \%, 4.1 \%, 3.48 \%, 2.7 \%$ respectively as compared to best parent. Line $\mathrm{S}_{2}, \mathrm{~S}_{10}, \mathrm{~S}_{17}$, $\mathrm{S}_{5}$ and $\mathrm{S}_{3}$ showed Yield Advantage of $35.83 \%$,
$34.94 \%, \quad 33.12 \%, 32.94 \%$, and $32.59 \%$ respectively as compared to best check variety. The lowest grain yield per plant was recorded against $S_{14}(13.37 \mathrm{~g})$ followed by $\mathrm{S}_{8}$ $(15.97 \mathrm{~g})$ and $\mathrm{S}_{20}(16.73 \mathrm{~g})$.

The range, mean, genotypic, phenotypic and environmental variance, Genotypic coefficient of variation (GCV), Phenotypic coefficient of variation (PCV), Heritability (in broad sense), Genetic advance (GA) and Genetic advance as percent of mean of 30 RILs of Langulmota/Sambamahsuri derivatives, along with 3 check varieties of rice and 2 parents are presented in Table 3 . A wide range of variability was observed among the genotypes against all the characters studied. This would offer a good scope of selection for evolving promising desirable genotypes. In general, phenotypic variance was higher than the corresponding genotypic variance against all the characters. The genotypic coefficient of variation (GCV) ranged between 3.22 (days to maturity) and 34.43(number of florets per panicle). The phenotypic coefficient of variation (PCV) ranged between 3.29 (days to maturity) and 35.98 (number of florets per panicle). Highest estimates of genotypic and phenotypic variance were observed for number of florets per panicle, followed by number of grains per panicle, plant height at maturity, floret fertility (\%), while It was also observed that panicle weight, panicle length, grain length, grain breadth, kernel breadth, kernel length, grain $\mathrm{L} / \mathrm{B}$ ratio and kernel $\mathrm{L} / \mathrm{B}$ ratio showed less genotypic and phenotypic variance.

The magnitude of PCV was higher than GCV for all the traits studied, indicated that environmental influences on the expression of these traits. This observation was similar to earlier findings of Abdourasmane et al., (2016), Mohan et al., (2016), Senapati and Awneetkumar (2015), Akinwale et al., (2011). High estimates of PCV and GCV was 
obtained for number of florets per panicle, number of grains per panicle, panicles per plant, panicle weight, 1000 grain weight and number of secondary branches per panicle, while, kernel L/B ratio, grain yield, number of primary branches, panicle height, floret fertility\%, kernel length, grain breadth, grain length. Kernel breadth exhibited moderate GCV and PCV values (Table 3). Therefore, there was a large scope for improvement of these traits through precise selection and hybridization. These findings were corroborated earlier by Ashok et al., (2013) for number of panicles per plant, number of florets per panicle, number of grains per panicle, and panicle weight. By Malathi et al., (2015) for grain yield per plant. By Madakemohekar et al., (2015) for number of panicles per plant, and 1000 grain weight and by Devi et al., (2017) for number of grains per panicle.

Heritability ranged from $32.87 \%$ (number of panicles per plant) to $95.70 \%$ (days to $50 \%$ flowering). High heritability was recorded for majority of the traits viz., days to $50 \%$ flowering, plant height, kernel L/B ratio, kernel length, grain length, grain yield per plant, days to maturity, grain breadth, plant height, number of florets, grains per panicle, fertility\%, 1000 grain weight, number of primary branches per panicle, panicle weight, number of secondary branches per panicle, and kernel breadth. While grain breadth, grain L/B ratio, number of panicles per plant, and panicle length showed moderate heritability (Table 3). These findings are accordance with Rajamadhan et al., (2016) for plant height and days to 50\% flowering, Gupta et al., (2016) for grain yield and 50\% flowering, Devi et al., (2017) for plant height, grains per panicle, 1000 grain weight.

Genetic advance ranged from 0.31 (grain breadth) to 135.85 (number of florets per panicle). High estimate of genetic advance was obtained for number of florets per panicle, plant height, and number of grains per panicle (Table 3). Lowest genetic advance was obtained against grain breadth followed by grain L/B ratio, kernel breadth, and kernel L/B ratio. Comparable results were obtained earlier, by Vijay et al., (2015) for number of florets per panicle, Revathi et al., (2016) for number of grains per panicle, and Anis et al., (2016) for plant height.

High estimates of heritability coupled with high genetic advance were obtained for number of florets per panicle, number of grains per panicle and plant height. These findings were similar with that of Vijay et al., (2015) for number of florets per plant. Similar findings were reported by Revathi et al., (2016) for number of grains per panicle, and Anis et al., (2016) for plant height.

High heritability along with high genetic advance as per cent of mean was obtained, number of florets per panicle, 1000 grain weight, and floret fertility\%, number of secondary branches per panicle, plant height and number of grains per panicle. This was in agreement with the findings of Ashok Kumar et al., ( 2013) for number of florets per panicle, Gokulakrishnan et al., ( 2015) for number of grains per panicle, Abdoursamne et al.,(2016) for days to 50\%flowering, and Devi et al.,(2017) for plant height, 1000 grain weight, it indicated the predominance of additive gene action for controlling these traits. Therefore, selection based on phenotypic performance would be effective for the improvement of these traits. High heritability with moderate to low genetic advance as percent of mean was observed for days to $50 \%$ flowering, days to maturity, number of primary branches per panicle grain length, and kernel breadth which suggested both additive and non-additive gene action for controlling these traits. 
Table.1 Analysis of variance for different characters of 30 RILs of Langulmota/Sambamahsuri derivatives along with parents and check varieties of rice (Mean sum of square)

\begin{tabular}{|c|c|c|c|c|}
\hline & & \multicolumn{3}{|c|}{ Source of variation with degrees of freedom(d.f.) } \\
\hline & & Replication(1) & Genotypes(34) & Error(34) \\
\hline 1 & Days to $50 \%$ maturity & 8.229 & $53.210 * *$ & 1.170 \\
\hline 2 & Days to maturity & 0.514 & $43.738 * *$ & 0.985 \\
\hline 3 & Plant height(cm) & 0.862 & $1035.077 * *$ & 37.887 \\
\hline 4 & No of panicles per plant & 26.414 & $8.039 *$ & 4.061 \\
\hline 5 & Panicle weight(g) & 0.123 & $1.248 * *$ & 0.304 \\
\hline 6 & Panicle length $(\mathrm{cm})$ & 0.940 & $3.859 *$ & 1.944 \\
\hline 7 & No.of primary branches per panicle & 0.036 & $3.256 * *$ & 0.801 \\
\hline 8 & No.of secondary branches per panicle & 13.729 & $55.354 * *$ & 10.761 \\
\hline 9 & Number of Florets per panicle & 1126.971 & $9939.881 * *$ & 438.943 \\
\hline 10 & Number of grains/panicle & 453.697 & $3023.059 * *$ & 433.441 \\
\hline 11 & Floret fertility (\%) & 7.136 & $159.906^{* *}$ & 20.222 \\
\hline 12 & 1000 grain weight $(\mathrm{g})$ & 1.094 & $34.351 * *$ & 1.538 \\
\hline 13 & Grain length(mm) & 0.012 & $1.343 * *$ & 0.068 \\
\hline 14 & Grain breadth(mm) & 0.015 & $0.132 *$ & 0.043 \\
\hline 15 & Grain $\mathrm{L} / \mathrm{B}$ ratio & 0.090 & $0.451 * *$ & 0.005 \\
\hline 16 & Kernel length(mm) & 0.033 & $0.878 * *$ & 0.040 \\
\hline 17 & Kernel breadth(mm) & 0.008 & $0.174 *$ & 0.036 \\
\hline 18 & Kernel L/B ratio & 0.004 & $0.405 * *$ & 0.073 \\
\hline 19 & Yield/plant $(g)$ & 7.623 & $40.584 * *$ & 2.466 \\
\hline
\end{tabular}


Table.2.1 Mean performance of 30 RILs of Langulmota/Sambamahsuri derivatives along with parents and check varieties of rice for different Characters

\begin{tabular}{|c|c|c|c|c|c|c|c|c|c|c|c|c|c|c|c|c|c|c|c|}
\hline Genotype Designation & 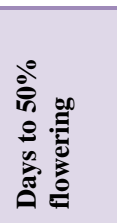 & 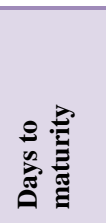 & 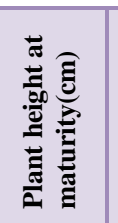 & 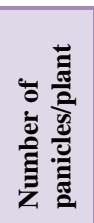 & 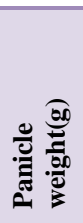 & 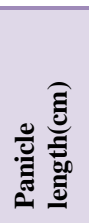 & 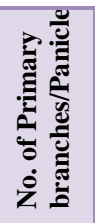 & 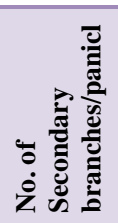 & 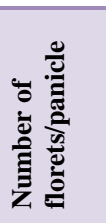 & 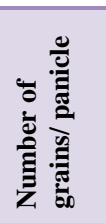 & 部 & 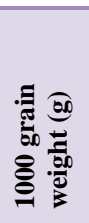 & 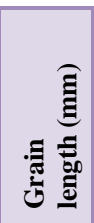 & 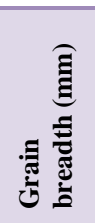 & 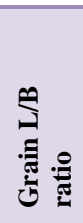 & 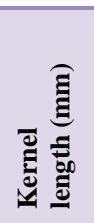 & 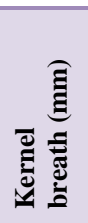 & 串 & 离 \\
\hline $1 . \mathrm{S}_{1}$ & 114.50 & 145.00 & 145.50 & 8.50 & 2.93 & 19.90 & 11.06 & 26.82 & 218.52 & 141.14 & 72.33 & 16.37 & 8.49 & 2.38 & 3.59 & 5.31 & 2.01 & 2.67 & 22.36 \\
\hline $2 . S_{2}$ & 120.50 & 150.00 & 154.50 & 11.00 & 3.54 & 22.80 & 12.40 & 36.70 & 247.50 & 179.05 & 74.80 & 15.26 & 7.95 & 2.58 & 3.08 & 5.16 & 1.79 & 2.88 & 30.63 \\
\hline $3 . S_{3}$ & 120.50 & 149.50 & 150.50 & 8.50 & 3.28 & 22.42 & 11.46 & 28.20 & 235.00 & 172.14 & 72.40 & 15.12 & 8.15 & 2.52 & 3.24 & 5.80 & 1.98 & 2.92 & 29.90 \\
\hline $5 . S_{5}$ & 119.00 & 151.00 & 140.00 & 9.50 & 2.97 & 22.14 & 12.45 & 28.40 & 202.45 & 162.25 & 83.94 & 16.06 & 8.24 & 2.52 & 3.30 & 5.19 & 1.75 & 2.98 & 29.98 \\
\hline $6 . S_{6}$ & 119.50 & 146.50 & 140.50 & 6.00 & 3.49 & 21.55 & 9.77 & 21.50 & 166.85 & 138.07 & 82.55 & 29.03 & 8.27 & 3.09 & 2.68 & 6.51 & 2.56 & 2.54 & 25.18 \\
\hline $7 . S_{7}$ & 114.00 & 144.50 & 121.0 & 5.00 & 1.31 & 22.08 & 10.6 & 19.80 & 96.30 & 83.40 & 86.43 & 13.04 & 7.47 & 2.37 & 3.15 & 5.07 & 1.98 & 2.56 & 22.90 \\
\hline $8 . S_{8}$ & 118.50 & 146.50 & 137.00 & 6.50 & 2.63 & 23.32 & 9.30 & 29.20 & 143.37 & 100.80 & 70.30 & 21.19 & 9.77 & 2.21 & 4.41 & 6.84 & 1.94 & 3.58 & 15.97 \\
\hline 9.S & 109.50 & 139.50 & 139.00 & 8.00 & 3.19 & 23.34 & 10.73 & 34.60 & 316.01 & 148.00 & 55.07 & 15.03 & 7.98 & 2.44 & 3.28 & 5.83 & 2.04 & 2.85 & 21.87 \\
\hline $10 . S_{10}$ & 114.50 & 144.50 & 145.50 & 6.00 & 4.74 & 21.55 & 13.16 & 31.00 & 358.12 & 220.37 & 61.43 & 17.86 & 7.80 & 2.32 & 3.37 & 5.22 & 2.59 & 2.01 & 30.43 \\
\hline 11.S $S_{11}$ & 113.50 & 141.50 & 145.50 & 7.50 & 3.17 & 23.24 & 11.40 & 27.60 & 278.58 & 186.50 & 66.18 & 16.49 & 7.42 & 2.57 & 3.24 & 5.78 & 2.00 & 2.89 & 29.09 \\
\hline $12 . S_{12}$ & 115.00 & 143.50 & 134.50 & 6.00 & 3.17 & 19.31 & 8.45 & 24.10 & 267.76 & 180.50 & 74.65 & 14.83 & 7.66 & 2.39 & 3.24 & 4.69 & 2.03 & 2.31 & 23.80 \\
\hline $14 . S_{14}$ & 120.00 & 146.50 & 141.00 & 6.00 & 2.54 & 19.53 & 9.81 & 27.06 & 241.43 & 123.19 & 54.12 & 16.01 & 8.11 & 2.62 & 3.10 & 5.76 & 2.26 & 2.55 & 13.34 \\
\hline $15 . S_{15}$ & 110.00 & 140.00 & 159.50 & 6.50 & 3.06 & 22.43 & 11.76 & 37.00 & 266.78 & 182.50 & 67.69 & 14.52 & 6.55 & 2.44 & 2.75 & 5.05 & 2.54 & 2.00 & 22.22 \\
\hline 16. $S_{16}$ & 108.50 & 138.00 & 145.00 & 6.50 & 2.82 & 21.75 & 11.08 & 31.58 & 216.08 & 145.57 & 74.17 & 16.77 & 8.27 & 2.49 & 3.31 & 4.99 & 2.26 & 2.20 & 23.45 \\
\hline 17. $S_{17}$ & 107.50 & 134.50 & 156.50 & 6.50 & 3.64 & 22.97 & 11.81 & 38.87 & 262.12 & 167.75 & 74.56 & 16.88 & 8.14 & 2.62 & 3.12 & 6.07 & 2.29 & 2.64 & 30.02 \\
\hline $18 . S_{18}$ & 113.00 & 142.00 & 138.0 & 11.50 & 1.90 & 23.30 & 8.76 & 25.52 & 170.60 & 93.30 & 61.85 & 18.48 & 8.73 & 2.12 & 2.60 & 6.57 & 2.14 & 3.06 & 19.87 \\
\hline 19.S $S_{19}$ & 111.00 & 139.50 & 133.50 & 10.00 & 2.70 & 19.67 & 9.73 & 27.93 & 163.92 & 97.84 & 74.64 & 16.01 & 8.42 & 2.18 & 3.89 & 6.19 & 2.07 & 2.98 & 24.77 \\
\hline $20 . S_{20}$ & 120.00 & 147.50 & 159.00 & 7.50 & 2.47 & 23.70 & 12.58 & 24.63 & 131.52 & 102.19 & 71.84 & 21.09 & 6.08 & 2.66 & 2.28 & 4.77 & 2.39 & 1.99 & 16.73 \\
\hline
\end{tabular}


Table.2.2 Mean performance of 30 RILs of Langulmota/Sambamahsuri derivatives along with parents and check varieties of rice for different Characters: (continued)

\begin{tabular}{|c|c|c|c|c|c|c|c|c|c|c|c|c|c|c|c|c|c|c|c|}
\hline Genotype Designation & 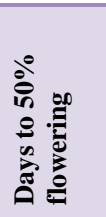 & 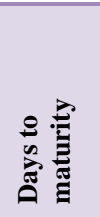 & 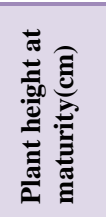 & 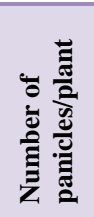 & 包 & 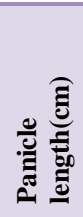 & 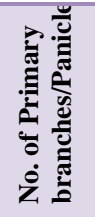 & 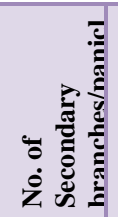 & 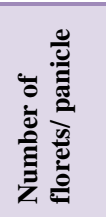 & 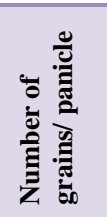 & 昰 & 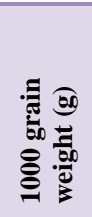 & 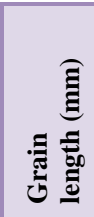 & 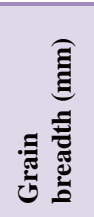 & 纯 & 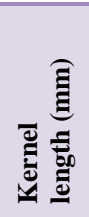 & 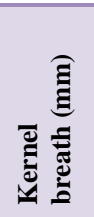 & 递 & \\
\hline 21. $S_{21}$ & 111.50 & 144.50 & 163.50 & 7.50 & 3.43 & 24.28 & 14.56 & 28.70 & 162.53 & 135.04 & 83.87 & 21.28 & 7.83 & 2.23 & 3.55 & 5.54 & 2.73 & 2.05 & 26.51 \\
\hline $22 . S_{22}$ & 99.00 & 130.50 & 142.50 & 7.50 & 3.22 & 23.00 & 11.25 & 33.67 & 173.63 & 154.09 & 85.72 & 17.78 & 8.65 & 2.24 & 3.93 & 5.54 & 2.15 & 2.57 & 27.92 \\
\hline 23.S $S_{23}$ & 109.50 & 138.50 & 141.50 & 8.00 & 2.47 & 21.52 & 10.28 & 32.97 & 216.43 & 98.33 & 65.95 & 18.58 & 7.91 & 2.50 & 3.17 & 5.35 & 2.19 & 2.44 & 20.78 \\
\hline $24 . S_{24}$ & 114.00 & 144.50 & 145.50 & 11.50 & 2.55 & 23.31 & 10.64 & 27.75 & 184.45 & 122.85 & 68.76 & 14.69 & 7.37 & 2.30 & 3.21 & 5.40 & 2.17 & 2.48 & 30.25 \\
\hline $25 . S_{25}$ & 118.50 & 147.50 & 140.50 & 8.00 & 2.82 & 21.25 & 9.73 & 23.50 & 127.77 & 97.70 & 79.96 & 24.73 & 9.87 & 2.83 & 3.51 & 6.16 & 1.98 & 3.14 & 22.83 \\
\hline $26 . S_{26}$ & 119.50 & 147.00 & 119.50 & 9.50 & 3.18 & 25.06 & 10.69 & 31.13 & 169.81 & 126.44 & 74.47 & 20.02 & 8.07 & 2.82 & 2.87 & 5.77 & 2.66 & 2.16 & 27.37 \\
\hline $27 . S_{27}$ & 119.00 & 149.50 & 116.50 & 8.50 & 3.09 & 23.65 & 10.51 & 29.36 & 173.04 & 115.60 & 66.51 & 19.36 & 7.11 & 3.00 & 2.36 & 5.19 & 2.64 & 1.96 & 26.42 \\
\hline $28 . S_{28}$ & 113.50 & 143.50 & 69.00 & 13.00 & 2.18 & 20.48 & 10.22 & 14.70 & 148.64 & 122.76 & 84.34 & 15.33 & 8.36 & 2.52 & 3.32 & 5.92 & 2.14 & 2.81 & 30.57 \\
\hline $29 . S_{29}$ & 114.50 & 143.50 & 148.50 & 10.00 & 2.26 & 22.70 & 11.06 & 28.77 & 151.31 & 118.87 & 80.88 & 16.20 & 7.37 & 2.39 & 3.11 & 5.08 & 2.26 & 2.24 & 24.30 \\
\hline 30.S $S_{30}$ & 102.50 & 134.50 & 100.50 & 9.00 & 2.75 & 24.25 & 10.40 & 29.30 & 140.21 & 95.43 & 68.08 & 24.33 & 9.25 & 2.15 & 4.32 & 7.78 & 2.40 & 3.23 & 26.31 \\
\hline 31.Langulmota & 116.50 & 144.50 & 151.50 & 6.00 & 5.11 & 22.23 & 12.33 & 30.56 & 199.21 & 125.16 & 84.10 & 30.76 & 9.05 & 3.09 & 2.93 & 6.02 & 2.55 & 2.36 & 29.23 \\
\hline 32.Samba Mahsuri & 121.00 & 148.50 & 83.50 & 9.00 & 2.29 & 21.97 & 10.62 & 28.9 & 152.00 & 100.54 & 65.45 & 18.91 & 7.94 & 2.70 & 2.93 & 5.80 & 2.52 & 2.30 & 26.40 \\
\hline 33.Dhanrasi (NC) & 113.00 & 143.00 & 107.61 & 10.00 & 2.31 & 23.74 & 9.42 & 19.89 & 143.55 & 107.97 & 75.40 & 18.72 & 8.44 & 2.82 & 3.00 & 5.81 & 2.92 & 1.98 & 22.26 \\
\hline 34. Swarna Sub1(RC) & 112.00 & 142.00 & 81.00 & 11.50 & 1.70 & 22.09 & 10.66 & 26.99 & 128.77 & 74.50 & 57.45 & 17.50 & 7.52 & 2.63 & 2.88 & 5.05 & 2.45 & 2.06 & 18.17 \\
\hline 35. Sabita(LC) & 118.00 & 144.00 & 132.50 & 8.00 & 2.76 & 21.51 & 9.87 & 24.50 & 119.94 & 94.00 & 81.21 & 25.38 & 9.76 & 2.90 & 3.37 & 6.81 & 1.98 & 3.51 & 22.55 \\
\hline Overall Mean & 114.43 & 143.69 & 135.26 & 8.27 & 2.95 & 22.30 & 10.90 & 28.61 & 200.21 & 134.26 & 72.35 & 18.42 & 8.10 & 2.54 & 3.20 & 5.66 & 2.24 & 2.58 & 24.85 \\
\hline CD & 2.19 & 2.01 & 12.49 & 4.09 & 1.11 & 2.83 & 1.81 & 6.65 & 42.52 & 42.29 & 9.07 & 2.51 & 0.53 & 0.42 & 0.93 & 0.39 & 0.38 & 0.53 & 3.30 \\
\hline
\end{tabular}

NC: National check, RC: Regional check, LC: Local check, CD: Critical difference 
Table.3 Variability and genetic parameters for different characters of Langulmota/Sambamahsuri derivatives along with parentsand check varieties

\begin{tabular}{|c|c|c|c|c|c|c|c|c|c|c|c|}
\hline \multirow[t]{2}{*}{ S.No } & \multirow[t]{2}{*}{ Plant character } & \multirow[t]{2}{*}{ Range } & \multirow[t]{2}{*}{ Mean } & \multicolumn{3}{|c|}{ Variance } & \multirow[t]{2}{*}{ GCV } & \multirow[t]{2}{*}{ PCV } & \multirow[t]{2}{*}{$h^{2}(b s)$} & \multirow[t]{2}{*}{ GA } & \multirow{2}{*}{$\begin{array}{c}\text { GA as \% } \\
\text { of Mean }\end{array}$} \\
\hline & & & & GV & $\mathbf{P V}$ & $\mathbf{E V}$ & & & & & \\
\hline 1 & Days to $50 \%$ flowering & $99.00-120.50$ & 114.43 & 26.02 & 27.19 & 1.17 & 4.46 & 4.56 & 95.70 & 10.28 & 8.98 \\
\hline 2 & Days to maturity & $130.50-151.00$ & 143.69 & 21.38 & 22.36 & 0.98 & 3.22 & 3.29 & 95.60 & 9.31 & 6.48 \\
\hline 3 & Plant height at maturity $(\mathrm{cm})$ & $69.00-163.50$ & 135.6 & 498.59 & 536.48 & 37.89 & 16.51 & 17.12 & 92.94 & 44.34 & 32.78 \\
\hline 4 & No of panicles per plant & $5.00-13.00$ & 8.27 & 1.99 & 6.05 & 4.06 & 17.05 & 29.74 & 32.87 & 1.67 & 20.14 \\
\hline 5 & Panicle weight $(\mathrm{g})$ & $1.31-5.11$ & 2.95 & 0.47 & 0.78 & 0.31 & 23.28 & 29.82 & 60.92 & 1.11 & 37.43 \\
\hline 6 & Panicle length $(\mathrm{cm})$ & $19.31-25.06$ & 22.30 & 0.96 & 2.90 & 1.94 & 4.39 & 7.64 & 33.01 & 1.16 & 5.19 \\
\hline 7 & No. of primary branches per panicle & $8.45-14.56$ & 10.91 & 1.23 & 2.03 & 0.80 & 10.16 & 13.06 & 60.52 & 1.78 & 16.28 \\
\hline 8 & No. of secondary branches per panicle & $14.70-38.87$ & 28.61 & 22.29 & 33.05 & 10.76 & 16.50 & 20.09 & 67.44 & 7.99 & 27.92 \\
\hline 9 & Number of florets per panicle & $96.30-420.29$ & 200.21 & 4750.57 & 5189.46 & 438.89 & 34.43 & 35.98 & 91.54 & 135.85 & 67.85 \\
\hline 10 & Number of grains per panicle & $74.50-236.30$ & 134.26 & 1293.86 & 1727.86 & 434.00 & 26.79 & 30.96 & 74.88 & 64.12 & 47.76 \\
\hline 11 & Floret fertility (\%) & $54.12-86.43$ & 72.35 & 70.31 & 90.28 & 19.97 & 11.59 & 13.13 & 77.89 & 15.24 & 21.07 \\
\hline 12 & 1000 grain weight $(\mathrm{g})$ & $13.04-30.76$ & 18.42 & 16.41 & 17.95 & 1.54 & 21.99 & 23.00 & 91.43 & 7.98 & 43.32 \\
\hline 13 & Grain length(mm) & $6.08-9.87$ & 8.10 & 0.65 & 0.72 & 0.07 & 9.98 & 10.49 & 90.44 & 1.58 & 19.54 \\
\hline 14 & Grain breadth(mm) & $2.12-3.09$ & 2.54 & 0.04 & 0.09 & 0.05 & 8.29 & 11.67 & 50.43 & 0.31 & 12.13 \\
\hline 15 & Grain $\mathbf{1} / \mathbf{b}$ ratio & $2.28-4.41$ & 3.20 & 0.11 & 0.32 & 0.21 & 10.35 & 17.77 & 33.92 & 0.40 & 12.42 \\
\hline 16 & Kernel length(mm) & $4.69-7.78$ & 5.66 & 0.43 & 0.47 & 0.04 & 11.59 & 12.09 & 91.85 & 1.30 & 22.87 \\
\hline 17 & Kernel breadth(mm) & $1.73-2.92$ & 2.24 & 0.07 & 0.11 & 0.04 & 11.71 & 14.46 & 65.56 & 0.44 & 19.53 \\
\hline 18 & Kernel 1/b ratio & $1.96-3.58$ & 2.58 & 0.17 & 0.24 & 0.07 & 15.99 & 19.00 & 70.81 & 0.71 & 27.71 \\
\hline 19 & Seed Yield/plant(g) & $13.34-30.63$ & 24.85 & 19.12 & 21.77 & 2.65 & 17.60 & 18.78 & 87.82 & 8.44 & 33.97 \\
\hline
\end{tabular}


In conclusion, the wide variability observed in the studied characters indicates the scope of effective selection. It should be highlighted that both parents performed better than the checks. Most of the characters as mentioned above displayed high heritability suggesting that additive gene action is playing a predominant role. The present investigation highlighted the differential performance of the selected lines of Langulmota/Sambamahsuri derivatives. Some of the derivatives were promising that displayed yield advantage over both the parents and checks; Lines $\mathrm{S}_{2}, \mathrm{~S}_{28}$, $\mathrm{S}_{10}, \mathrm{~S}_{24}, \mathrm{~S}_{17}$ were shown yield advantage $4.78 \%, \quad 4.58 \%, \quad 4.1 \%, \quad 3.48 \%, \quad 2.7 \%$ respectively as compared to best parent.Line $\mathrm{S}_{2}, \mathrm{~S}_{10}, \mathrm{~S}_{17}, \mathrm{~S}_{5}$ and $\mathrm{S}_{3}$ showed yield advantage of $35.83 \%, 34.94 \%, 33.12 \%, 32.94 \%$, and $32.59 \%$ respectively as compared to best check variety. They may be carried forward for multilocation/environmental trials for testing their stability and adaptability across the environments.

\section{References}

Abdourasmane, K., Konate, Adama, Z., Honore, K., Ambaliou, S and Audebert, A. ( 2016).Genetic variability and correlation analysis of rice (Oryza sativa L.) inbred lines based on agromorphological traits. African Journal of Agriculture Research. 11(35): 33403346.

Akinwale, M.G., Gregorio, G., Nwilene, F., Akinyele, B.O., Ogunbayo, S.A and Odiyi, A.C. ( 2011). Heritability and correlation coefficient analysis for yield and its components in rice (Oryza sativa L.). African Journal of Plant Science. 5(3): 207-212.

Al Jibouri, H.A., Miller, P.A. and Robinson, H.F. (1958), "Genetic and environmental variances and covariances in an upland cotton cross of interspecific origin", Agronomy
Journal, 50: 633-637.

Anis, G.B., EL -Namaki R.A., AL-Ashkar I.M., Barutcular C., EL Sabagh A.(2016). Yield potential and correlation analysis of some rice hybrids for yield and its component traits. Journal of Animal and Plant Sciences. 30(2): 4748-4757.

Ashok K.T., Singh, S. K., Amita S. and Bhati, P.K. (2013). Appraisal of genetic variability for yield and its component characters in rice (Oryza sativa L.). Journal of Bio Life. 1(3):84-89.

Devi K. Rukmini, Chandra B. Satish, Lingaiah N., Hari Y., Venkanna V (2017). Analysis of variability, correlation and path coefficient studies for yield and quality traits in rice (Oryza Sativa L.). Agricultural Science Digest. 37(1), 1-9.

Gokulakrishnan, J., Sunil, K. B and Prakash, M. (2014). Variability studies for some yield and quality traits inRice (Oryza sativaL.). Plant Archives, 14(1): 533536.

Gupta R., Tetwar S., Khute I.K., Nair S.K (2016). Quantitative Analysis of Rice Germplasm of Chhattisgarh. Advances in Life Science, 5(3): 1034-1038.

Guyer, D., Tuttle, A., Rouse, S., Volrath, S., Johnson, M., Potter, S., Gorlach, J., Goff, S., Crossland, L and Ward, E. (1998). Activation of latent 171 transgenes in arabidopsis using a hybrid transcription factor. Genetics. 149:633639.

Johnson, H.W., Robinson, H.F. and Comstock, R.E. (1955), Estimation of genetic and environmental variability in soyabean", Agronomy Journal, 47: 314318.

Madakemohekar, A.H., Mishra, D.K., Chavan, A.S and Bornare, S.S. (2015). Genetic variability, correlation and path analysis of RIL's derived from inter subspecific crosses for yield and its 
component traits in rice (Oryza sativa L.). A Quarterly Journal of Life Sciences. 12(1): 190-193.

Malathi, D., Selvi, B., and Maheswaran, M, (2015). Genetic Variability Studies for Yield and Yield Contributing Traits in Rice. Centre for Plant Breeding and Genetics, 8(12), 0974-8, 3060-3063.

Mohan, Y.C., Srinivas, B., Thippeswamy S. and Padmaja, D (2016) Diversity and variability analysis for yield parameters in rice (Oryza sativa L) genotypes. Indian Journal of Agricultural Research. 50(16):14-19.

Rajamadhan R., Murugan (2016).Genetic Variability, Correlation and Path Coefficient Studies for Grain Yield and Other Yield Attributing Traits in Rice (Oryza sativa L.). Journal of Advances in Life Science.9: 2145- 2150.

Revathi, S., Sakthivel, K., Manonmani, S., Umadevi, M., Ushakumari, R. and S. Robin (2016). Genetics of wide compatible gene and variability studies in rice (Oryza sativa L.). journal of Genetics. 95: 463-467.

Senapati and Awneetkumar (2015). Genetic assessment of some phenotypic variants of rice (Oryza sps) for some quantitative characters under the Gangatic plains of West Bengal. African journal of biotechnology, 14(3): 87-201.

Vijay, K., Navin K., Suresh, B.G. ( 2015). Systematic Evaluation of Exotic Rice Germplasm for Yield Component Characters and Its Grain Yield. International Journal of Research Studies in Biosciences.3(3): 53-55.

\section{How to cite this article:}

Rashad Khan, B.K. Senapati, P.L. Sangeeta and Shaik Shamim Ahmed. 2019. Variability and Heritability Studies in the Recombinant Inbred Lines (F8) of Langulmota/Sambamahsuri Derivatives of Rice (Oryza sativa L.). Int.J.Curr.Microbiol.App.Sci. 8(04): 467-476. doi: https://doi.org/10.20546/ijcmas.2019.804.050 